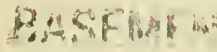




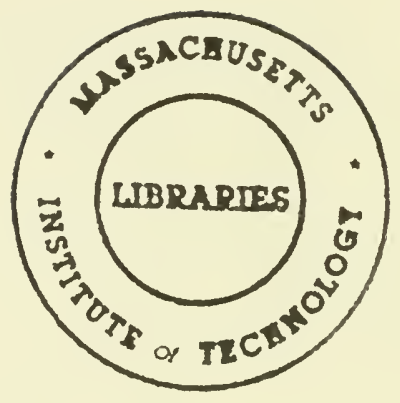






\section{WORKING PAPER}

\section{ALFRED P. SLOAN SCHOOL OF MANAGEMENT}

MANAGING PRODUCT LINES THAT SHARE
A COMMON CAPACITY BASE

\section{by}

A John D.W. Morecroft WP1331-82

\section{MASSACHUSETTS}

INSTITUTE OF TECHNOLOGY

50 MEMORIAL DRIVE

CAMBRIDGE, MASSACHUSETTS 02139 

MANAGING PRODUCT LINES THAT SHARE

\section{A COMMON CAPACITY BASE}

by

A John D.W. Morecroft

WP1331-82 



\section{MANAGING PRODUCT LINES THAT SHARE \\ A COMMON CAPACITY BASE ${ }^{1,}$ ?}

$$
\text { by }
$$

John D. W. Morecroft*

Assistant Professor

Alfred P. Sloan School of Management

Massachusetts Institute of Technology

Revised January 1982

* The author is indebted to Jeffrey G. Miller, Stephen C. Graves, and James M. Lyneis for comments received on earlier drafts of this paper.

1 The original title of this working paper was "Structures Causing the Erosion of Secondary Sales," March 1981.

2 The analysis presented in this paper was supported by funds from a joint M.I.T./corporate research project. Preparation of the paper was supported by the System Dynamics Corporate Research Program of the Sloan School of Management, M.I.T. 


M.T. LIBRAAIES
OCT 261982
RECENVEO




\title{
MANAGING PRODUCT LINES THAT SHARE \\ A COMMON CAPACITY BASE
}

\author{
ABSTRACT
}

This paper examines the difficulties of managing the competitive profile of product lines which share a common capacity base. The analysis is derived from a case study of a manufacturing firm that produces finished product and service parts at a single plant. Finished product and service parts are treated as a special case of two product lines. A system dynamics simulation model is used to represent production and ordering policies within the firm and its distribution network. Simulation analysis shows that these policies cause demand volatility in the finished product to be converted into supply volatility of service parts, leading to loss of service parts market share. To improve the performance of the service parts business, the production of finished product and parts should be decoupled, so the supply of the two product lines becomes independent. The results are discussed for the general multiproduct-line case. A brief report of implementation results is included. 


\section{MANAGING PRODUCT LINES THAT SHARE}

\section{A COMMON CAPACITY BASE}

\section{INTRODUCTION}

In many manufacturing firms, product lines with different market characteristics share a common capacity base. When a single manufacturing facility must cater for a variety of product lines, it becomes increasingly difficult to devise manufacturing policies that will satisfy the diverse marketing needs of all product lines. Some product lines may be very price-sensitive or delivery-sensitive. Others may have inherently volatile and unpredictable demand patterns. The result can be conflicting priorities in production, complexity of production planning, and competitive weakness of one or more product Iines.

In this paper we draw on a case study of a manufacturing firm which produces finished product and service parts at a single plant. We treat finished product and service parts as a special case of two product lines, where the product lines have clearly differentiated market characteristics. A system dynamics simulation model is used to represent production and ordering policies within the firm and its distribution network. Simulation analysis shows that these policies cause demand volatility in finished product to be converted into supply volatility of service parts. Since the major need of service parts is reliable and short delivery time, loss of service parts 

market share results. Under the prevailing set of operating policies, the service parts business finds itself in a weak competitive position, pincered between volatile capacity constraints and a delivery-sensitive market.

Simulation runs of the model are used to explain how the competitive weakness of the service parts business results directly from the operating policies of the firm and why those policies are able to persist despite their damaging effect. The simulation model is also used to explore policy changes that will strengthen the service parts business. The major policy recommendation is to decouple finished product and service parts production, so that the supply of the two product lines becomes independent.

Although the analysis is based on a specific case study of service parts, it has general implications for multiproduct-line manufacturing, which are developed at the end of the paper. In addition a brief report is provided of the implementation of policy recommendations arising from the case.

2. A PERSPECTIVE ON THE NATURE OF THE ANALYSIS

This paper treats an area that has been the focus of much work in operations management. It deals with issues of aggregate production planning in a setting where two demand streams (assumed to be highly correlated) share a common capacity base. The early work of 

Holt, Modigliani, Muth and Simon (HMMS) [6] and the more recent hierarchical production planning methods described by Bitran and Hax [2] and Hax and Meal [5] have shed much light on optimal scheduling of such a system. However, this paper should not be regarded as an attempt to cover the same ground. Its purpose is fundamentally different. Rather than examining how an efficient schedule should be set, it examines why, in a complex organization, inefficient schedules are likely to exist and to be sustained over time. In particular it shows how an organizational structure composed of many reasonable and rational policies can lead to a form of inefficiency that causes loss of market share in a product line.

The system dynamics model used in the analysis is primarily a descriptive model of organizational process, much more closely related to the behavioral models of Cyert and March [3] and the Carnegie school than to normative optimizing models of the HMMS kind. ${ }^{1}$ The model portrays a considerable breadth of decision making from the ordering decision of a retail network through to aggregate production planning, capacity planning, and capacity allocation decisions of the original equipment manufacturer, OEM. Decision functions are descriptive of the actual decision-making processes that have evolved in the real system. Simulation is used to understand how these decision functions interact over time. Only when an understanding of the system behavior has been acquired through careful scrutiny of

1 For a discussion of the organizational and behavioral aspects of system dynamics models see Morecroft [12]. 

simulation runs, is the model then used in a normative sense to devise better policies than those which currently prevail in the system.

The interpretation given to the analysis has been greatly aided by the manufacturing strategy concepts of writers such as Skinner and Miller. Skinner [14] talks about the concept of a focused factory in which products with different marketing needs are completely separated in production by the creation of a "plant within a plant," or PWP. This kind of manufacturing strategy has marked parallels to the policy of separation proposed later in the paper.

Miller [10] also talks about the concept of focus as one element of strategic choice in designing manufacturing systems that are consistent with marketing strategy. In addition, in joint work with Van Dierdonck [15] he indicates that focus can be increased by the introduction of slack resources. The relation between focus and manufacturing slack (in the form of inventory) is central to the detailed design of the policy of separation described later.

\section{BACKGROUND TO THE CASE AND MODEL OVERVIEW}

The case involves a manufacturer of consumer durables operating in a highly seasonal market. The manufacturer supplies a network of retail outlets with both finished product (also referred to as primary product) and sercive parts (also referred to as secondary product). The retail outlets are independent businesses responsible 

for selling the product to the final customer and for stocking and ordering product and parts. At the time the project was undertaken, the manufacturer had become concerned about loss of service parts market share and high manufacturing costs. It was to these two problems that analysis was directed.

Figure 1 shows the arrangement of subunits within the overall manufacturing and distribution organization. Although the focus is on manufacturing policy within the OEM (original equipment manufacturer), it seemed essential to consider the retail network because of its importance in defining the differing characteristics of the primary and secondary product markets.

Subunits 1 and 2 on the left of the figure represent a standard two-stage production and distribution network involving the primary business of retailers and OEMs. Subunits 3,4 , and 5 on the right of the figure represent the production and distribution network of the secondary business, which is similar to the primary network but includes alternative secondary sources with which retailers can place orders. Subunit 6 in the lower center of the figure represents capacity management and allocation within the original equipment manufacturer. The subunit couples the primary and secondary businesses according to their common dependence on capacity. In the paragraphs that follow, there will be a brief description of the major policies within each subunit. The reader is assumed to have some familiarity with the typical structure of production and distribution 



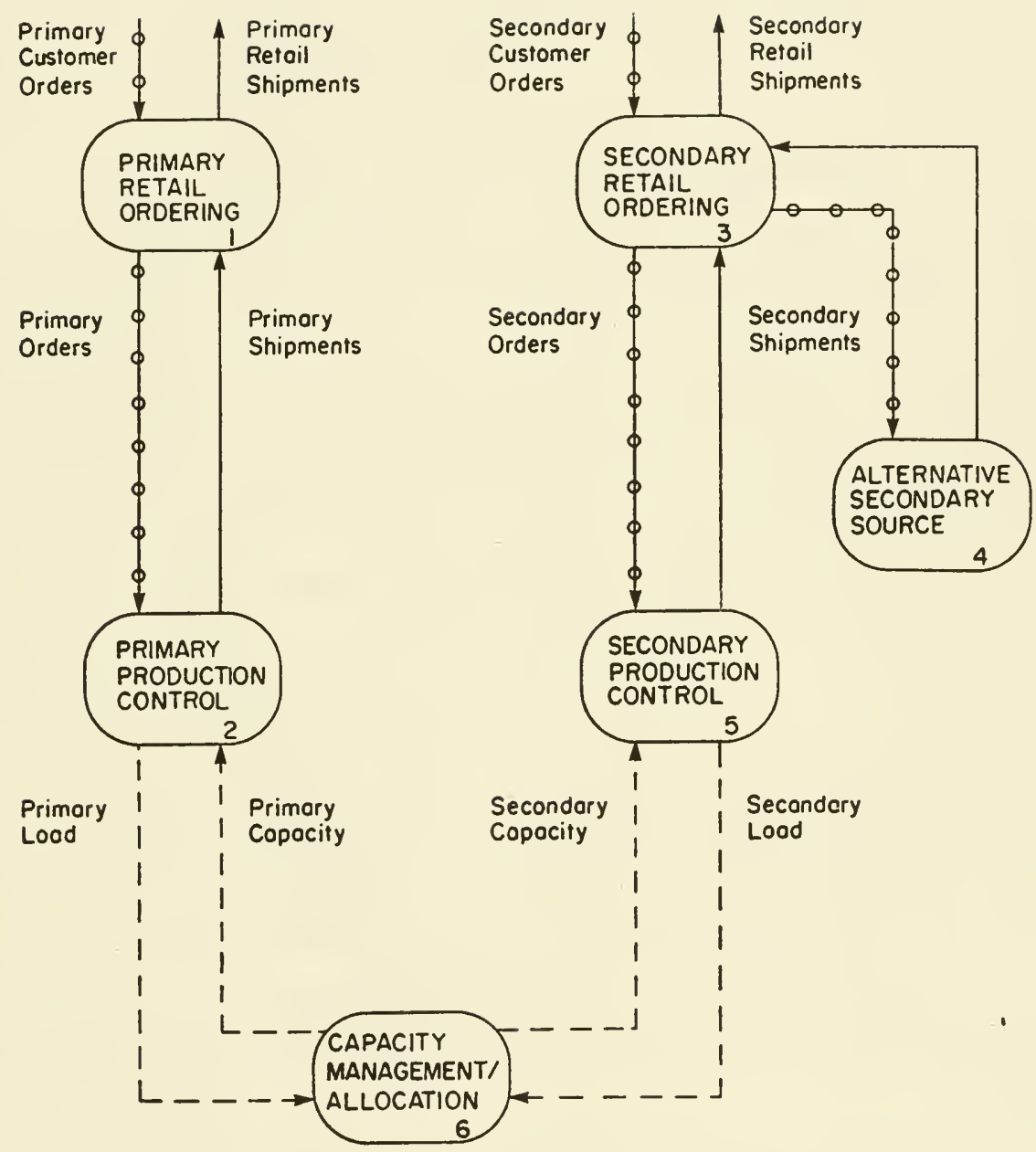

Figure 1. Overview of Coupled Primary and Secondary Businesses 

networks and their portrayal in system dynamics. ${ }^{2}$ Policy structure diagrams and full equation listings for each subunit are provided in the appendices. The reader with some business experience need not be familiar with the detail of the appendices to follow the arguments that are developed later in the paper.

Consider first the operation of subunit 1 , primary retail ordering. Orders are received from the customer, and shipments of finished product are made in return. Within the subunit are located the forecasting and inventory control policies that guide retail ordering and encompass the inventory and service objectives of retailers. As a whole, the retail network prefers to sell from inventory and consequently carries a large stock of finished product, between two and three months' coverage of sales. Retailers order aggressively in the event of supply shortages, tending to overorder to ensure adequate supplies.

Subunit 2 contains production planning and control within the original equipment manufacturer. The subunit receives orders from retailers and makes shipments in return. Within production control are located the OEM's aggregate production planning, encompassing forecasting, inventory control, and backlog control. The OEM follows

2 For further information see Forrester [4] and Lyneis [8, pp. 143-210]. 

a produce and ship-to-order policy, carrying only small quantities of finished inventory (historical records showed that the company rarely carried more than two weeks' finished product, despite strongly seasonal demand) and adjusting production plans quickly in response to unexpected changes in demand.

Subunits 3 and 5 of the secondary network are closely analogous in internal structure to primary subunits 1 and 2 . The only notable difference is that the OEM tries to follow a ship-from-stock policy for service parts, rather than the ship-to-order policy used in the primary business. In addition, however, the secondary network contains subunit 4 representing alternative secondary sources. The alternative secondary sources are small suppliers that specialize in the service parts business. They produce parts that can be used interchangeably with the parts of the original equipment manufacturer. Alternative suppliers are an important feature of the competitive environment in secondary sales. They ensure their existence by providing prompt delivery, which is a major competitive variable in the secondary market.

It was found from discussion that retailers will order from an alternative source only if OEM delivery times are noticeably worse than times quoted by the small specialist suppliers. Faced with equal delivery times from OEM and an alternative source, retailers will prefer to order from the OEM. 

Subunit 6 in the lower center of the figure represents capacity management and allocation within the OEM. Capacity is adjusted to support the production needs of the primary and secondary businesses. If either primary or secondary demand rises, the capacity management subunit will acquire additional capacity, usually by expanding the workforce. Capacity is allocated between primary and secondary production, giving preference to primary production when capacity shortages develop.

The rationale for a biased capacity allocation policy seemed to revolve around both the political weight of the primary business and consideration of revenue loss. The primary business is a much larger part of the company, accounting for more than $70 \%$ of revenues. There are many more people within its ranks who carry more influence. Consequently, when a capacity shortage develops, primary production receives more of the scarce capacity resource. A shortfall in primary production is a more visible problem than in secondary production and has a more immediate and obvious effect on sales. Furthermore, the threat of revenue loss from primary production cutbacks is at first sight much greater than from secondary production cutbacks, despite the well-known high margin on secondary sales. Secondary production tends to operate from a weak bargaining base when it comes to capacity allocation.

With this picture of the system in place, several structural features can be identified that should be borne in mind in the later analysis. The model is basically a pair of production and 

distribution networks that are coupled through a common capacity base deep within the manufacturing process. The relative size of the networks is rather skewed, since the primary network is about eight times the size of the secondary network in terms of capacity needs. The secondary business operates in a very sensitive and constraining capacity environment in which small primary capacity shortages can be translated into relatively large secondary capacity shortages by the allocation policies. Furthermore, the secondary business operates in a market environment in which the competition is composed of specialist parts producers that do not face such restrictive and volatile capacity constraints. The simulation experiments of the next two sections explore the repercussions of this scenario in more detail.

\section{EXPERIMENTAL DESIGN}

The objective of the simulation experiments is to expose the difficulties of managing the secondary business within the constraining capacity environment that results from sharing capacity with the primary business. Of course, it does not take much imagination to realize that a capacity allocation policy biased in favor of primary production is likely to be detrimental to the secondary business. What is more difficult to realize is just how detrimental even a mild allocation bias can be within the setting of coupled production and distribution networks. 

Two simulation experiments are used to develop understanding of the reasons for competitive weakness of the secondary business. First we use the complete model to show that volatility of demand, arising in the structure of the primary production distribution network, causes unreliable supply of service parts. Then we use a simplified model to explain the persistence of the existing operating policies. We argue that the source of problems for the secondary business is invisible within individual subunits of the organization. Without a broad perspective on manufacturing and distribution, the existing policies seem reasonable and will stay in place.

4. COMPETITIVE WEAKNESS OF SECONDARY SALES- -AN ORGANIZATIONAL PROBLEM

In this section we examine the response of the entire manufacturing and distribution organization to a simultaneous $20 \%$ step increase ${ }^{3}$ in primary and secondary customer orders. 4 We examine the situation as it unfolds in different parts of the organization: in

3 A simultaneous primary and secondary increase can be interpreted to represent a market in which primary and secondary demand are highly correlated. Such correlation is common in products for which there is strongly seasonal demand. The reader should bear in mind that the demand increase is unexpected and cannot be anticipated in its timing or shape.

4

Secondary customer orders are expressed in "finished unit equivalents." Initially, secondary customer order rate is assumed to be the equivalent (in capacity terms) of 125 finished units per week. Primary customer order rate is initially set at 1,000 finished units per week. 



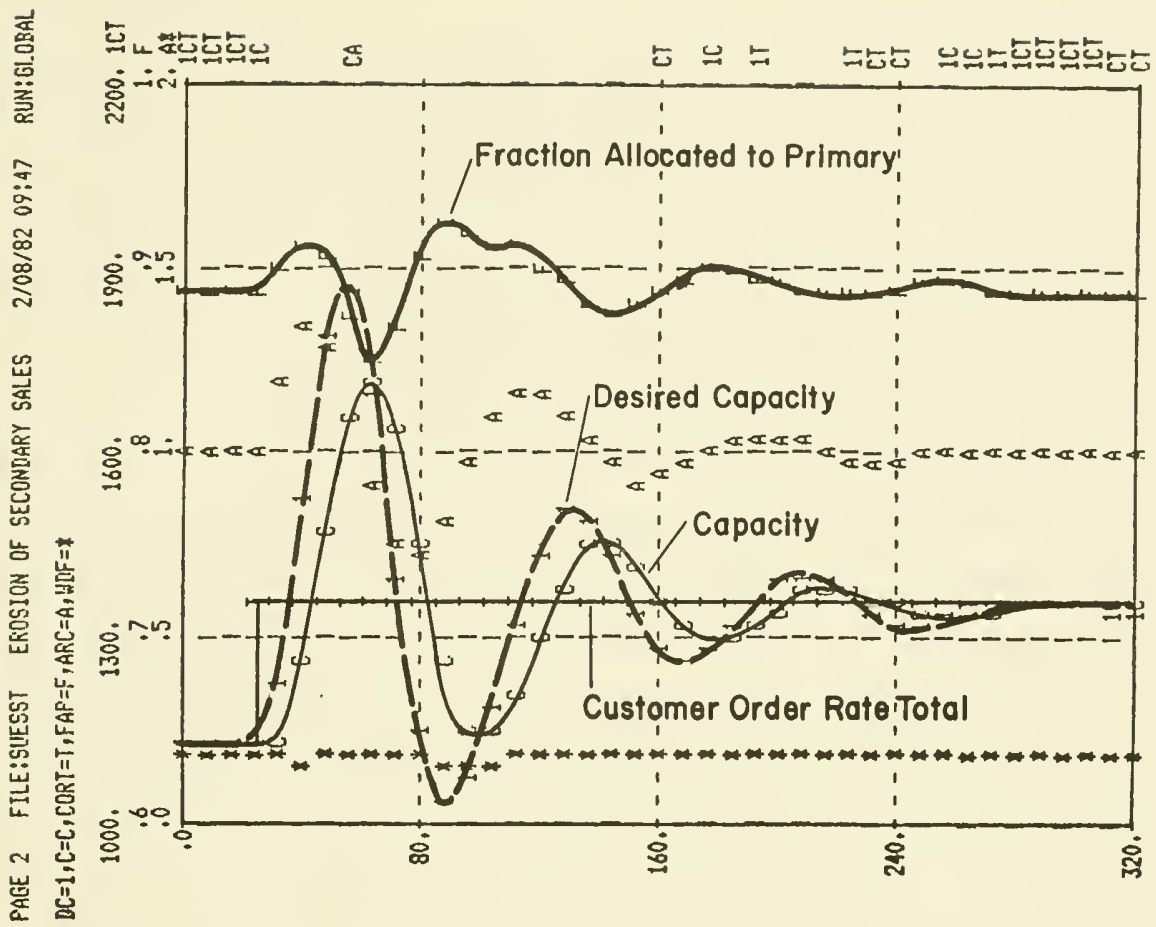

.

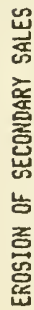

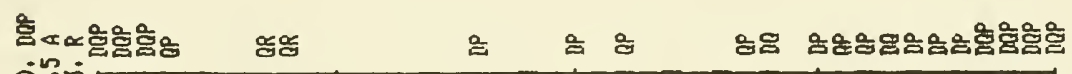

वे
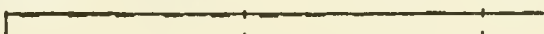

! 

capacity management, in production control, and in the retail network. The upper half of Figure 2 shows behavior in the capacity management subsystem. The 20\% step increase in customer orders is translated into a volatile and fluctuating requirement for manufacturing capacity as indicated by the trajectory of desired capacity. Capacity requirements do not simply follow the change in customer order rate. Inventory and forecast adjustments made in retail ordering and production scheduling amplify the base-customer requirements. Capacity is seen to fluctuate around the equilibrium customer order rate with a period of about 120 weeks. (A detailed explanation of the causes of demand amplification and fluctuation is beyond the scope of this paper. Readers should note that such behavior of production and distribution systems had been observed empirically in the work of Mack [9] and is believed by many economists, such as Abramovitz [1] and Klein and Popkin [7], to be the source of short-term business cycles in industrial economies. Readers who would like to see a detailed explanation of this behavior using system dynamics modeling are referred to Forrester [2] and Morecroft [11].)

The figure also shows the allocation of capacity to the primary business. The allocation starts off in equilibrium at .89 , commensurate with the large volume of primary business. Soon after the demand increase the primary allocation begins to rise, as primary production takes priority in the use of available capacity. As additional capacity comes on line, the fraction of capacity allocated to primary production begins to fall. Thereafter the allocation curve 

mirrors the trajectory for capacity. Whenever there is excess capacity, primary production takes less than its "equitable" share of capacity. Whenever there is a shortage of capacity, primary production takes more than its "equitable" share of capacity.

The lower half of Figure 2 shows behavior in the secondary production control subunit. Secondary customer order rate increases in a $20 \%$ step. In response, the secondary production rate actually falls initially. The fall occurs because capacity is being allocated to primary production. For a period of about twenty weeks, secondary production remains below the customer order rate, leading to a substantial rise in delivery delay for the secondary product (to a peak of approximately $21 / 2$ times the normal delay). The shortage of secondary production is followed by a period of catch-up and overshoot, in which secondary production greatly exceeds customer demand. Delivery delay quickly returns to normal. Secondary production rate continues to be volatile as it is pushed and pulled by the capacity needs of the primary business.

Suppose we now trace events as they are seen in the secondary portion of the retail subunit. Figure 3 shows the variables of particular interest to retail decision making. Customer orders, which are directly observable by the retailer, are shown increasing by $20 \%$. Soon after the increase, the retailers experience an increase in secondary delivery delay from the manufacturer. Delivery delay rises to a peak of 2.5 times normal and remains more than twice normal for around sixteen weeks, or four months. The rapid rise in delivery 

delay is, of course, directly attributable to the allocation policy in capacity management.

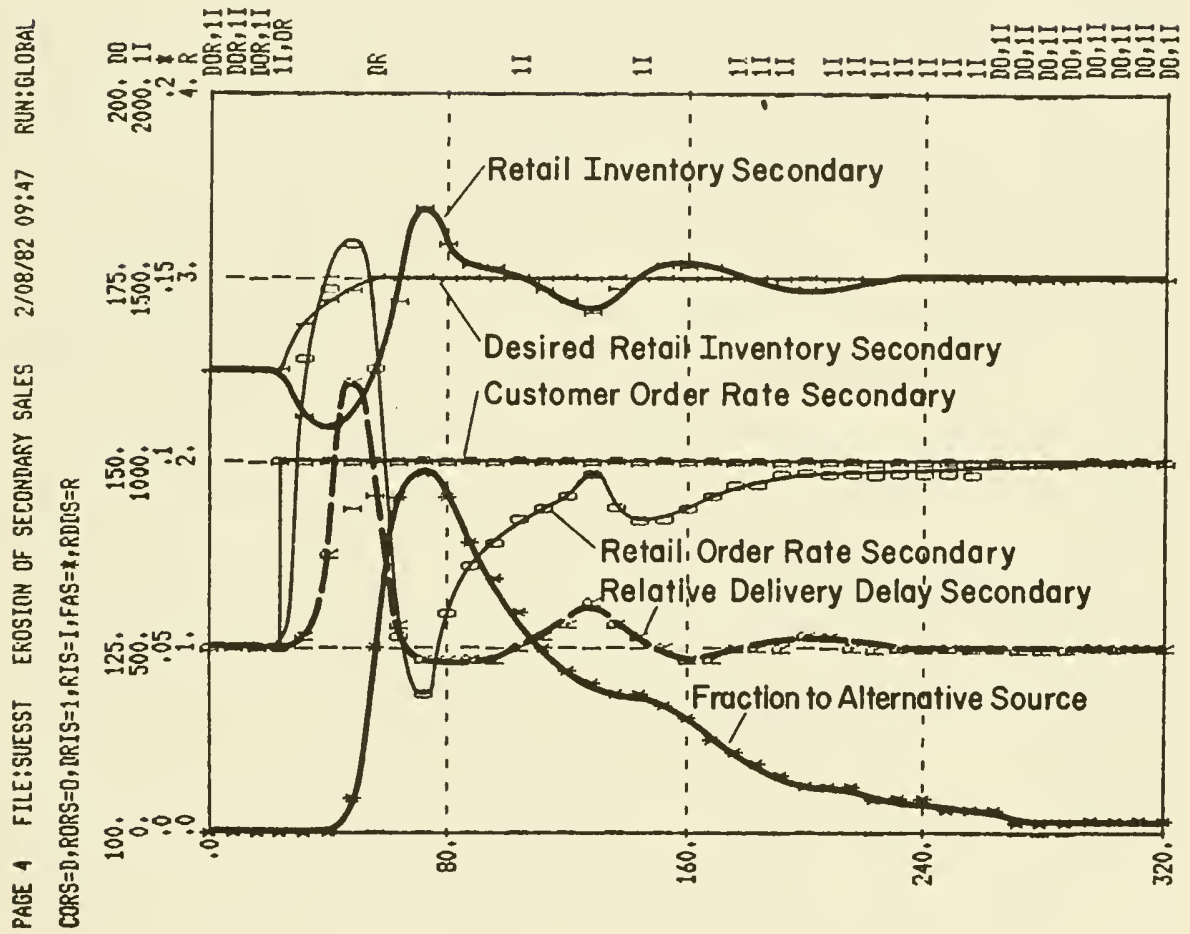

Figure 3. Secondary Retail Ordering and Allocation

But the retailer is not concerned with the rationale for the increase. From the retail perspective, secondary lead times become intolerably high. The percentage of secondary orders going to alternative sources increases to a peak of $10 \%$ by week 72 . Thereafter the OEMs slowly 

regain lost sales as they once again establish competitive secondary delivery times.

It should be pointed out that alternative sources are assumed to maintain constant delivery times in the face of the demand increase. It is this assumption that causes retailers to allocate orders in their favor. However, it is important to realize that the assumption is not lightly adopted, but reflects a very important aspect of the competitive character of th secondary market. Alternative sources are dedicated to parts manufacture and are not faced with difficult capacity allocation decisions. In such a dedicated manufacturing environment, the first response to an increase in secondary demand is an increase in secondary production. By contrast, in the OEM the first response to an increase in secondary demand (when it is accompanied by an increase in primary demand) is a decrease in secondary production. As a result, the OEM's secondary lead times are likely to be much more volatile. Furthermore, the secondary market is very sensitive to delivery. Delivery is the primary competitive variable. The entire system therefore tends to produce a delivery scenario in the retail subsystem that encourages alternative sourcing. The differences in organizational character of OEMs and alternative sources, coupled with the delivery sensitivity of the secondary market, conspire to cause loss of market share of the secondary business.

The last set of runs in this section fills in the remaining pieces of the organizational picture, showing the sources of schedule 



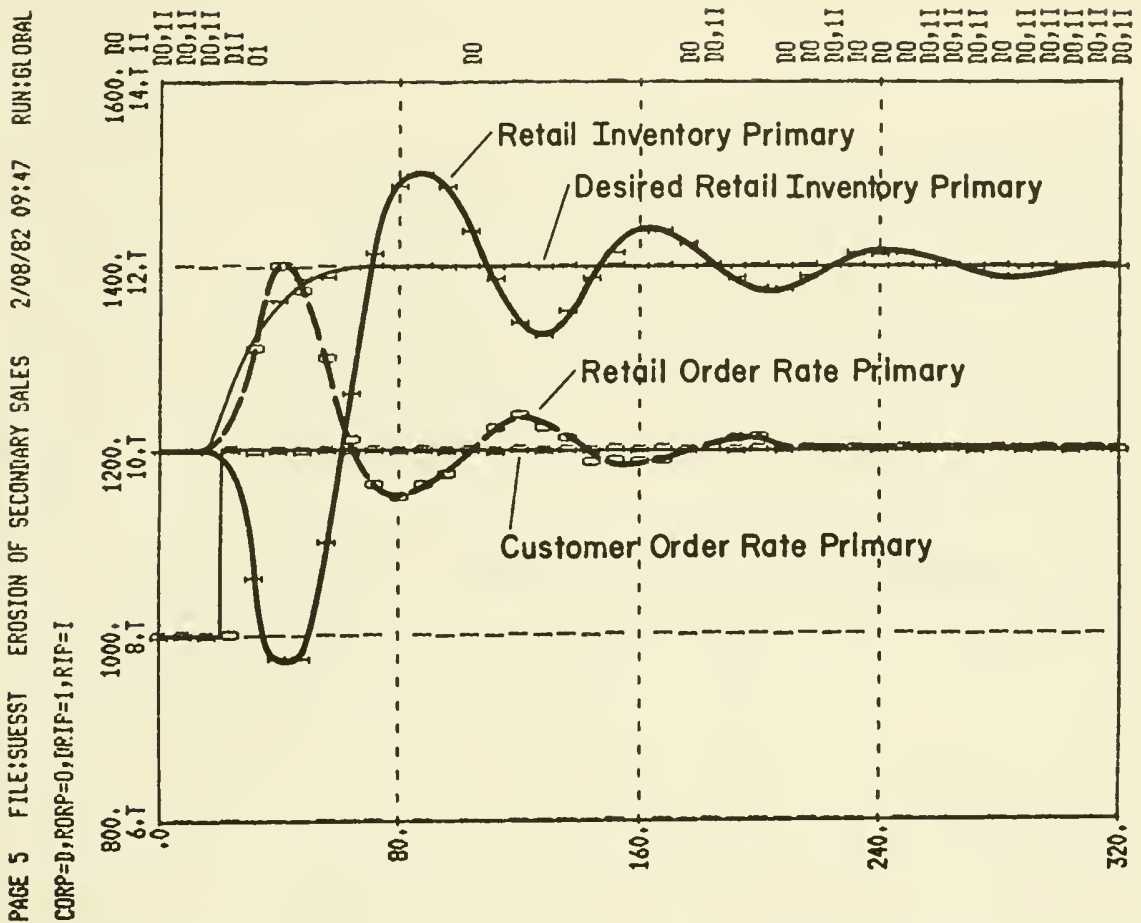

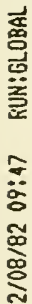

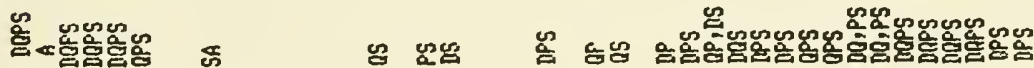
드의

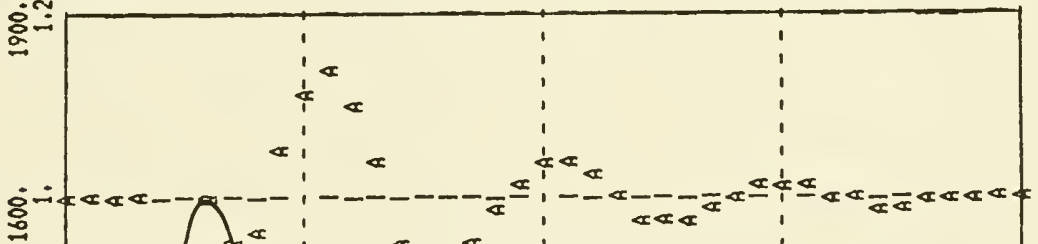

.

峞

$\infty$

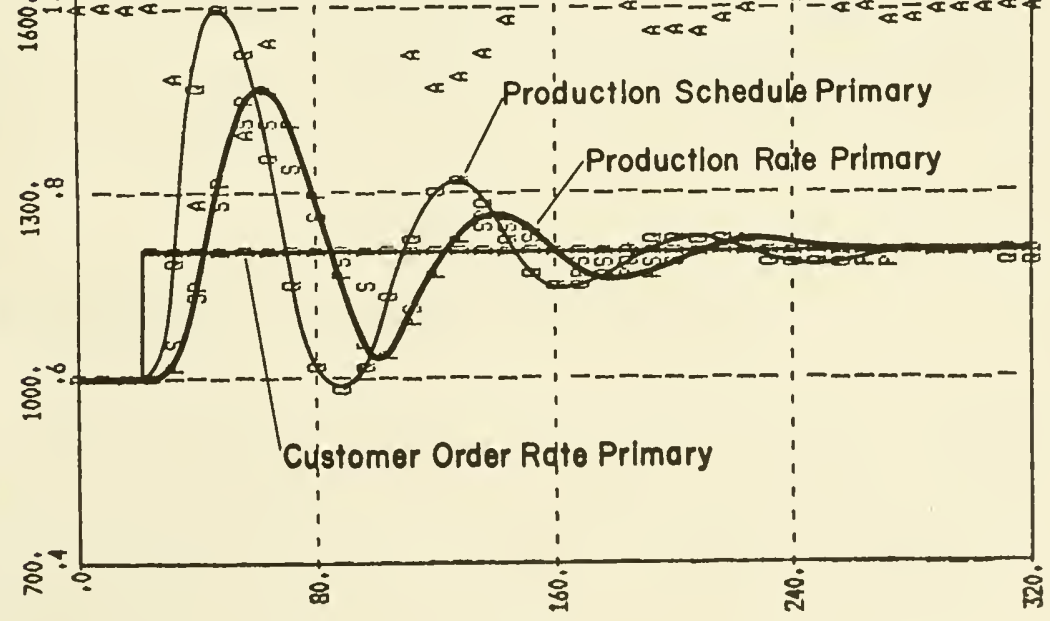

Figure 4. Primary Retail Ordering and Primary Production 

volatility in the primary business. Figure 4 shows the behavior of variables in the primary retail and production control subsystems. The retail subsystem, shown in the upper left of the figure, is the direct recipient of the $20 \%$ step increase in customer orders. But retail ordering is not a simple repeat of the customer order pattern. Policies for retail inventory control, coupled with supply constraints, cause retail ordering to follow a fluctuating path. The ordering and inventory patterns display the well-known dynamics of production and distribution referred to earlier.

In the lower half of the figure, primary production control responds to the varying retail order stream with a still more variable schedule. The greater schedule variability is again attributable to policies for inventory and backlog control coupled with capacity constraints. The primary production schedule increases to a peak of almost 600 units per week above its initial equilibrium value, even though customer orders increase by only 200 units per week. The organization places a much greater load on manufacturing than might at first seem necessary.

\section{INVISIBILITY OF THE PROBLEM AT THE SUBUNIT LEVEL}

The causes of competitive weakness of the secondary business are not clearly visible at the level of an individual subunit in the system. Supply volatility of secondary product does not arise from any one subunit, but from the joint interaction of policies in all 

subunits. Herein lies an explanation of why an inconsistent set of policies could have evolved in the organization. In the absence of any argument pointing out the policy inconsistencies, the existing policy set is likely to remain in place, with problems being blamed on external factors "beyond the control of management."

In this section we use a simplified version of the simulation model to demonstrate that policy inconsistency cannot be observed without a complete picture of organizational structure. In the simplified model, the dynamics of the retail network are excluded from the system. Of course, the simplified model is no longer representative of the real system, but it is likely to be representative of an incomplete perception or "mental model" of the system used to justify existing manufacturing policy.

Figure 5 shows a simulation $r$ un of the model subject to the same $20 \%$ increase in total customer order rate. The simulation run should be interpreted as the process of "thinking through" (with an incomplete mental model) the consequences of adjusting the manufacturing system to a sustained increase in demand. As we shall see, the adjustment of the simplified model is easier to interpret and more compatible with our intuition than the adjustment of the complete model.

Soon after the increase in customer orders, desired capacity begins to rise as capacity plans are adjusted to accommodate the higher volume of orders. The delay between the change in demand and 

desired capacity reflects a natural caution in capacity planning.

There is a need to be persuaded that a demand increase is permanent rather than transient before committing to capacity expansion. The level of capacity in the system also rises, but some time later than desired capacity, due to the delays in acquiring capacity once a commitment to expansion has been made. Nevertheless, the simulation run shows that capacity rises in a rational and timely way in response to the load change.

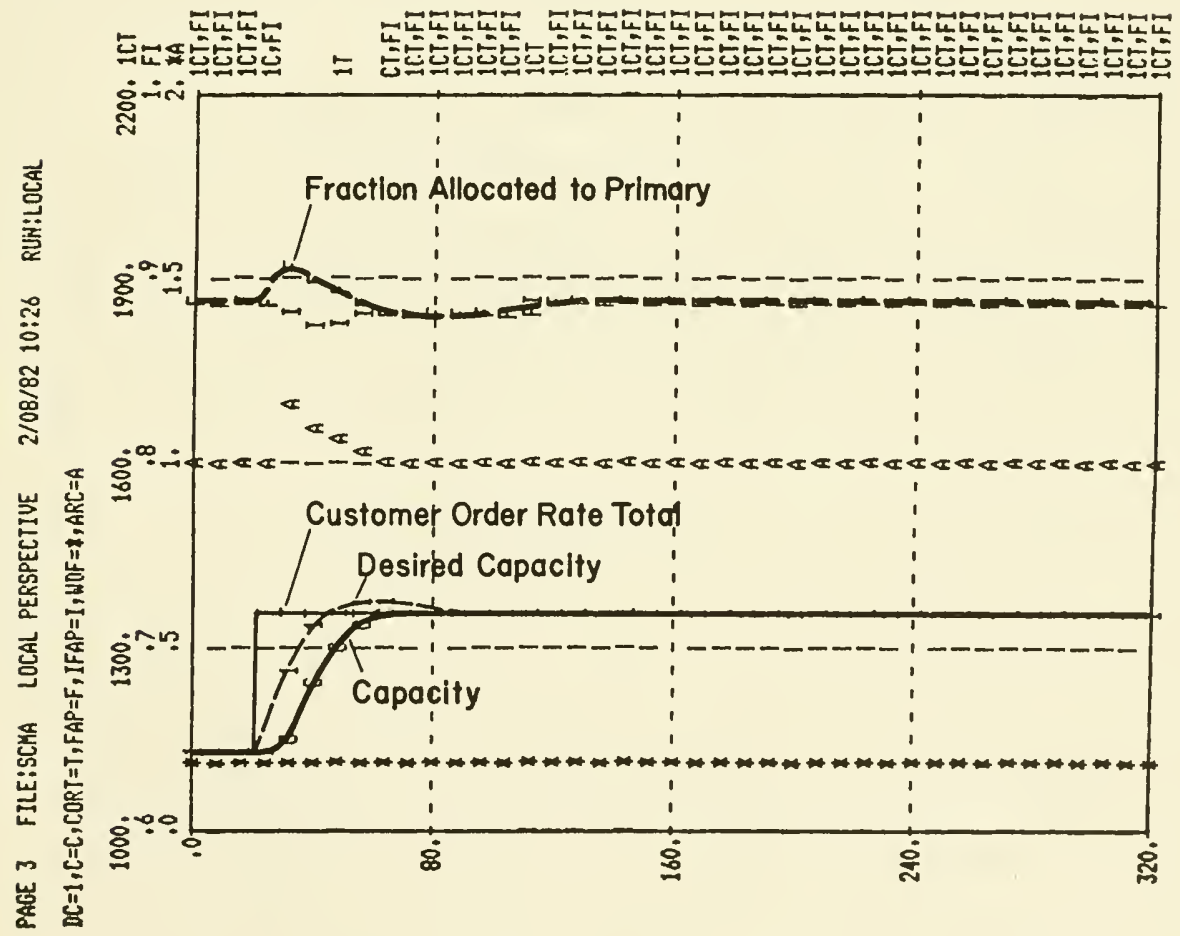

Figure 5. Capacity Adjustment and Allocation From Perspective of Surrogate Mental Model 

During the interval between week 24 and week 80 , there is a capacity shortage that activates the priority allocation process. In the upper half of the figure, the fraction (of capacity) allocated to primary production starts off from an equilibrium value of .89 . Soon after week 24 , the fraction increases above the equilibrium allocation as capacity shortage develops. The arrival of new capacity alleviates the capacity shortage, so that by week 72 capacity is once more "equitably" allocated between primary and secondary production. The allocation curves show a transient bias toward primary production, but not a bias that is likely to disrupt the secondary business.

The analysis so far suggests that large unexpected increases in market demand can be accommodated with only a minor, transient disturbance of production allocation. The analysis can be extended by imagining the consequences of the allocation bias as it affects secondary production and shipping. Again the argument is advanced from the incomplete perspective of our surrogate mental model.

In the lower half of Figure 6 are the trajectories for the secondary production schedule and production rate. As a reference, the secondary customer order rate is also plotted. At week 24, the customer order rate makes its $20 \%$ step increase. The secondary schedule increases soon after, as confidence builds that the demand increase is permanent. The secondary production rate, however, actually declines for a period of eight weeks, as the allocation policy draws secondary capacity for primary production. After week 32, the secondary business begins to regain its lost allocation, and secondary production recovers. 

In the upper half of the figure a curve for relative delivery delay is plotted. After the demand increase, relative delivery delay rises from its initial value of one ${ }^{5}$ until secondary production

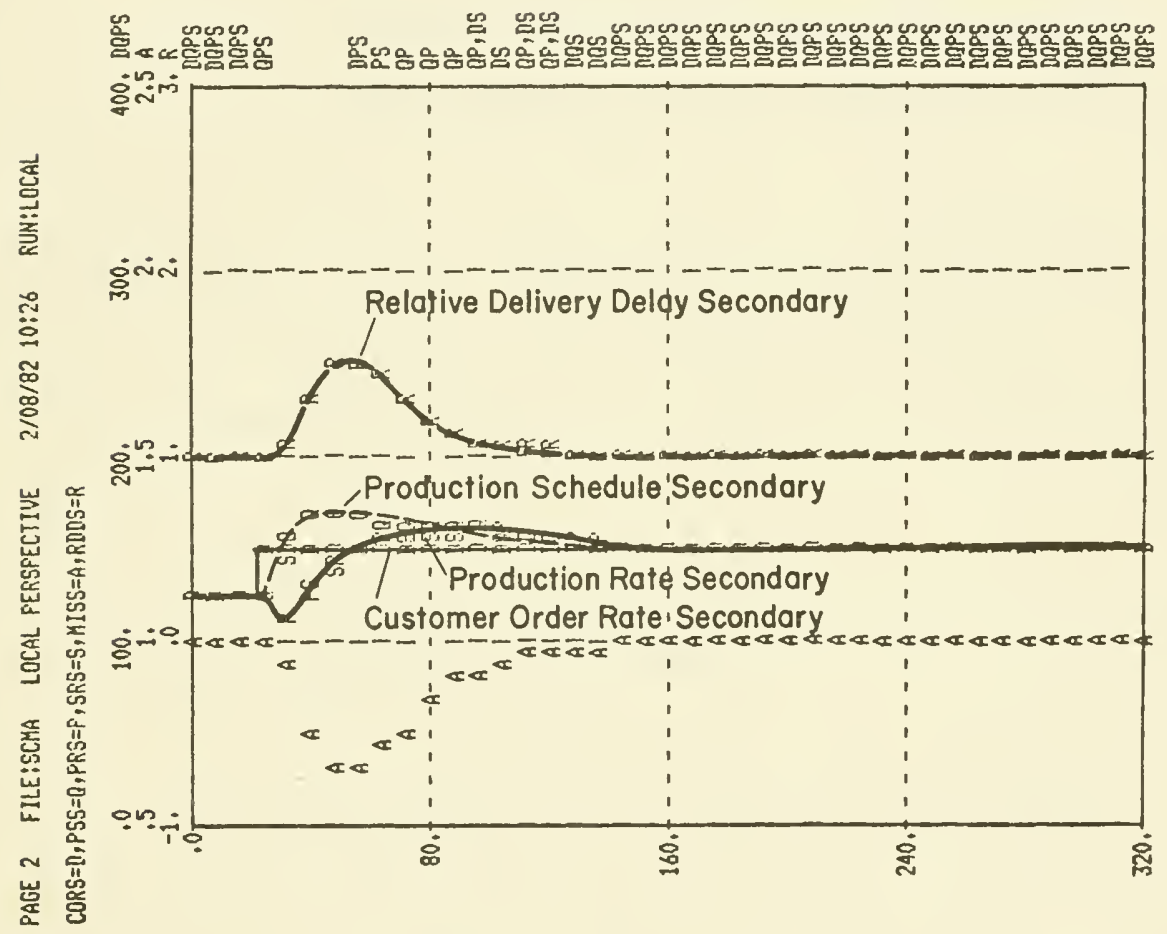

Figure 6. Secondary Production and Delivery From Perspective of Surrogate Mental Model

5

Meaning that delivery delay on secondary sales is equal to the delivery delay of alternative secondary sources. In this situation, it is assumed that retailers will prefer to order from the OEM. 

catches up with the new and higher rate of ordering in week 56 . At its peak, relative delivery reaches a value of 1.5 , meaning that secondary delivery times are $50 \%$ greater than the competitive norm.

The simulation run supports an opinion that the allocation policy in capacity management is not greatly damaging to the secondary business. A large change in primary and secondary demand results in a small, transient rise in delivery times. While the rise is not desirable, it is unlikely to encourage retailers to seek alternative sources of supply. It is the plausibility of opinions like this than can hold the existing policy structure in place--even though the structure is manifestly inefficient when viewed from a total-system perspective.

\section{POLICIES TO OVERCOME COMPETITIVE WEAKNESS}

To overcome competitive weakness of the secondary business, it is necessary to ensure a stable supply of service parts. One way to achieve this is to remove the allocation bias within capacity management. Removal of the allocation bias is easily tested within the model and can be shown to have beneficial effects. In reality, however, the solution would be difficult to implement. It would face strong organizational resistance because it runs counter to the political weight and powerful revenue-generating potential of the primary business. Even with a strong argument to support a neutral allocation policy, when faced with a capacity shortage the needs of the primary business would be likely to prevail. 

An alternative method of ensuring a stable supply of service parts is through an organizational policy change that alleviates capacity allocation pressures. It is possible to think of a number of such policy changes. All involve decoupling the primary and secondary businesses so they can operate independently. For example, a policy of increasing secondary finished inventory would be an example of a decoupling policy. Additional inventory would be held not as a buffer against secondary demand variations, but rather as a buffer against variations in primary capacity needs. Alternatively, a policy of primary production smoothing, implemented entirely within the primary business, would relieve capacity shortages, thereby benefiting the secondary business.

Figure 7 shows the results of implementing a production smoothing policy in primary production control, seen from the perspective of secondary retailing. ${ }^{6}$ The results are a great improvement on the original behavior seen in Figure 3. After the step increase in demand, relative delivery delay rises to a peak of around 1.5 by week 48 . The rise in delivery delay causes a small fraction of retail orders to go to alternative sources, but the peak fraction is only $3 \%$, by comparison with almost $10 \%$ in the system without the

6 The policy involves the following changes: Primary finished inventory target is increased from two weeks of shipments to eight weeks of shipments. Correction times in the linear control rules for inventory and backlog are doubled from sixteen to thirty-two weeks. The smoothing time in the exponential average used to represent forecasting is doubled from ten to twenty weeks. 

primary production smoothing policy. The secondary business becomes

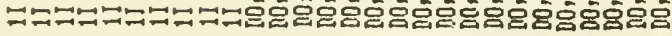

ㅎํ욤

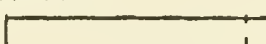



in which a manufactured product is sold. To ignore the linkage between manufacturing policy and marketing strategy is to significantly increase the probability of competitive weakness in one or more product lines.

In this paper we have taken a specific case study showing the difficulties of supporting primary product and service parts sales from a shared capacity base. The competitive posture of the service parts business was the focus of the analysis. Using a system dynamics simulation model of the manufacturing firm, we were able to identify two features of the policy structure of the organization that caused the secondary business to be a weak and ineffective competitor in the secondary market. First, since the primary business was much larger in terms of revenue and personnel, it tended to have priority of allocation during periods of capacity shortage. Second, capacity shortages could readily occur in the system because of high demand amplification in the policies of the primary production and distribution network. The combination of these two features caused the supply of service parts to be very volatile in a market where quick and reliable delivery is an important competitive variable.

To overcome this inherent weakness, policy changes should be adopted that create more independence for secondary production. Theoretically, removing allocation bias within capacity management would be effective but would likely run into a great deal of organizational resistance. 

A more practical policy is to deliberately invest in the separation of primary and secondary production. The paper illustrates one example of such a policy. Primary finished inventory investment is increased as a means of stabilizing the primary production schedule and thereby alleviating load variations on capacity from the primary business. With fewer capacity shortages, secondary production can be made more responsive to market variations, even without the elimination of capacity allocation bias.

Although the analysis was based on a specific case study, it has a number of general features that are of broad applicability. Most manufacturers sell through a distribution network, which tends to amplify demand variations of the customer. If the demands of many distribution networks are focused on a single manufacturing facility, production priority conflicts are likely to occur.

The analysis would suggest that careful thought be given to grouping products according to the characteristics of the markets they serve. The fewer the similarities of market characteristics, the more the supply of different product lines should be insulated (through the use of buffering inventories or independent plants-within-a-plant, PWPs). In addition, the analysis suggests that particular attention be paid to the situation where one product line, small in terms of volume (but perhaps highly profitable, as in the case of service parts), competes with much larger volume product lines. Then small adjustments of capacity in favor of the large volume product can have a greatly magnified effect on the small volume product. Such a 

situation would suggest that relative volume is a market

characteristic to be considered in grouping product lines.

\section{IMPLEMENTATION RESULTS}

The policy recommendations described above were the basis for an implementation effort in the company. Using the arguments of strengthening the secondary business and simultaneously lowering manufacturing cost in the primary business, authorization was obtained from the parent company for a \$15-million investment in primary finished inventory ${ }^{7}--a$ substantial investment in relation to the subsidiary company's annual revenues of approximately $\$ 200$ million. The model predicted a return on policy investment of not less than $20 \%$ per year.

A detailed implementation report was prepared for the company (Morecroft and Stephens [13]) showing how the new policy could be integrated into the existing informal production planning procedures of the organization. During the period of overlap between policy implementation and the end of the project, a marked smoothing of primary production was noted, accompanied by fewer instances of capacity shortages.

$7 \$ 15$ million was the maximum investment authorized to cover inventory buildup during the slow winter selling season. The average investment over the year was approximately $\$ 8$ million. 

The project did not extend for a sufficiently long period after implementation to observe its full impact on the secondary business. (Simulation runs suggest a one-to-two-year time lag before more reliable supply would clearly win back service parts market share.) Nevertheless, the project did have a considerable impact within the organization. It supplied a plausible rationale for manufacturing policy change and a rationale that was convincing enough to bring about a real commitment of resources to implement the change. 



\section{REFERENCES}

1. Abramovitz, M., Inventories and Business Cycles. New York: National Bureau of Economic Research, 1950.

2. Bitran, G. R. and A. C. Hax, "On the design of Hierarchical Production Planning Systems," Decision Sciences, Vol. 8, No. 1, January 1977, pp. 28-55.

3. Cyert, R. M. and J. G. March, A Behavioral Theory of the Firm. Englewood Cliffs, NJ: Prentice-Hall, 1963.

4. Forrester, J. W., Industrial Dynamics, Cambridge, MA: M.I.T. Press, 1961.

5. Hax, A. C. and H. C. Meal, "Hierarchical Integration of Production Planning and Scheduling," in Studies in Management Sciences, Vol. 1, Logistics, North Holland-American Elsevier, 1975, pp. 53-69.

6. Holt, C. C., F. Modigliani, J. F. Muth, and H. A. Simon, Planning Production, Inventories, and Workforce. Englewood Cliffs, $\mathrm{NJ}$ : Prentice-Hall, 1960.

7. Klein, L. R. and J. Popkin, "An Econometric Analysis of the Postwar Relationship Between Inventory Fluctuation and Change in Economic Activity." In Joint Committee (1961) pt. 3, pp. 71-86.

8. Lyneis, J. M., Corporate Planning and Policy Design. Cambridge, MA: M.I.T. Press, 1980.

9. Mack, Ruth P., Information, Expectations and Inventory Fluctuation, National Bureau of Economic Research, 1967.

10. Miller, J. G., "Fit Production Systems to the Task," Harvard Business Review, January-February 1981.

11. Morecroft, J. D. W., "Structures Causing Instability in Production and Distribution Systems," System Dynamics Group Working Paper D-3244-2, Sloan School of Management, M.I.T., Cambridge, MA 02139, January 1981.

12. Morecroft, J. D. W., "System Dynamics: Portraying Bounded Rationality," Proceedings of the 1981 Conference on System Dynamics Research, Rensselaerville, NY, 1981. (Copies available from System Dynamics Group, Sloan School of Management, M.I.T., Cambridge, MA 02139.

13. Morecroft, J. D. W., and C. A. Stephens, "Build-Planning Policy Handbook--An Implementation Report," System Dynamics Group Working Paper D-2992-1, Sloan School of Management, M.I.T., Cambridge, MA 02139 , November 1981. 

14. Skinner, W., "The Focused Factory," Harvard Business Review, May-June 1974.

15. Van Dierdonck, R., and J. G. Miller, "Designing Production Planning and Control Systems," Journal of Operations Management, Fall 1980. 

APPENDIX: MODEL DOCUMENTATION

Structure of Retail Ordering Subunits.............. (i) and (ii)

Structure of Production Control Subunits........... (iii) and (iv)

Structure of Capacity Allocation Subunit............ v v and (vi)

Equations for "Surrogate Mental Model"

Generating Local Perspective......................... vii)

List of Variable Names............................ viii) $-(x)$ 



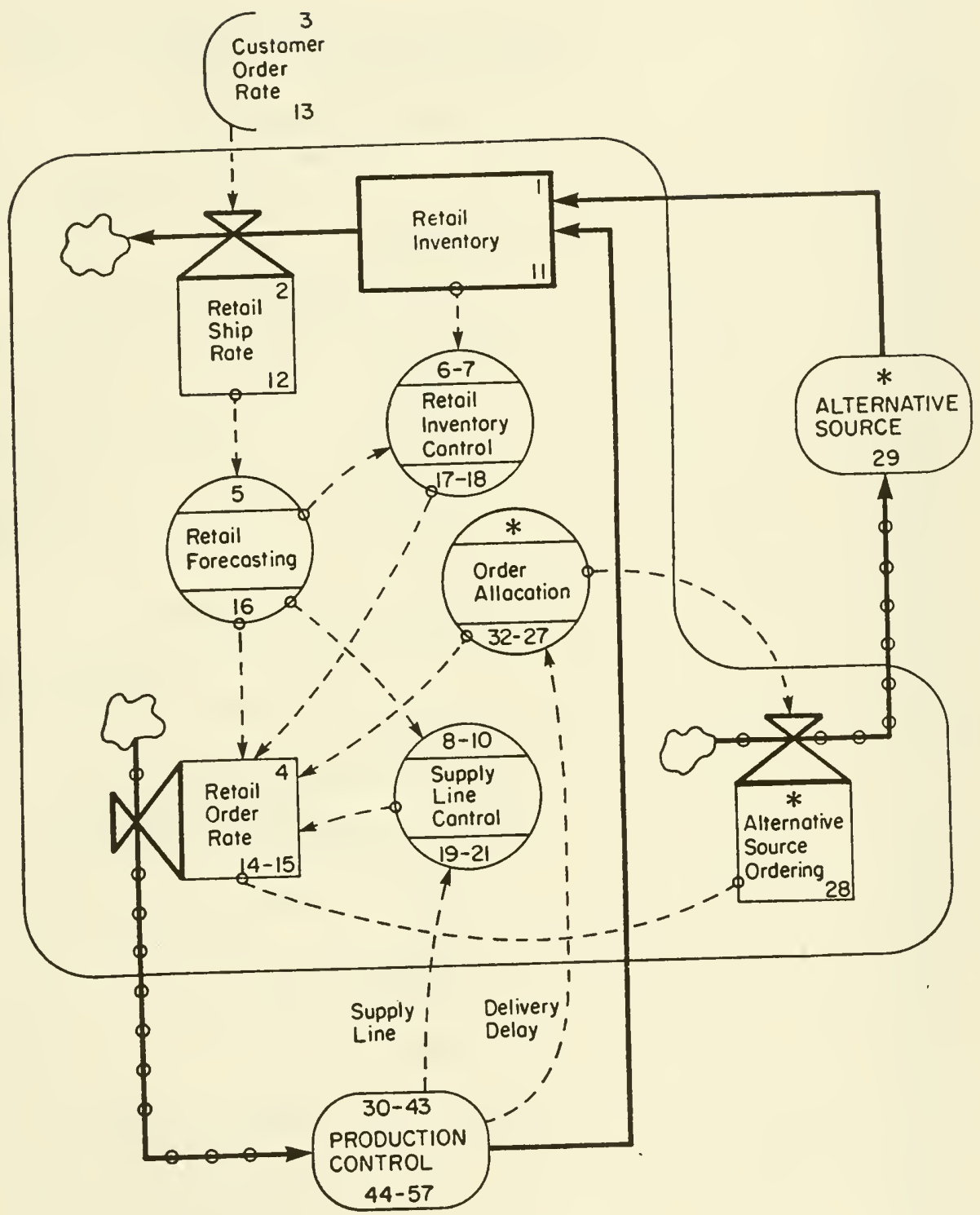

Note: Numbers correspond to equations in model listing. When two sets of numbers appear in a symbol, the upper numbers correspond to primary business and the lower to secondary business. When an "*" appears, there are no equations in the primary business corresponding to the symbol. 

NOTE

* EROSIDN OF SECOMNARY SALES

NOTE MOIEL TO ANALYSE STRLIICTURES IINIIEFL YING

NOTE. FROSTOY OF SECONQARY SALES TIN THE FROTIICTION

NOTE. ANII RETAILING OF CONSIIMEK IIIIRAELES (SUESS)

NOTE. RYY IOHN FI.W. MORECROFT JANIJARY 1981

NOTE

NOTE

NOTE.

** RETATL. ORIEER LiYG SURSYSTE. FRIMARY ***

$L \quad R I P, K=R I F, J+(I T)(S R F, J K-R S R F, J K)$

N RIF $=$ CORF $* N N^{\prime} I C F$

R RSRF, KI =CORF,K

A CORF, K=JDF*(1+STEF (SDF,TSDF))

C I DP $=1000$

C SDF $=0 / T$ SIIF $=2.4$

UNITS/WFEK

NOTE

NOTE CONTROL FOLICIES IN FRIMAFY ORDERING

$R$ KDRF, KL $=A C, \cap F, K+(C, T I F, K+C, S L, F, K)$

L ACORF'.K=ACORF, J+(IIT/TAC.OFF') (COFF, J-ACORF, J)

$N$ ACDFF = ITIF

C TACOFF $=10$

A CRIP,K $=(I I K I F, K-R I P, K) / T C R I P$

C TCRIF $=1$ 2

WEEKS

WEEKS

A DRIF,K=ACORP, KNWVRICF

C NRICF $=10$ WEEKS

A CSI.F $K=((D S L . P, K-S I . F, K) / T C S I . F)) W S L F$

C TCSLF $=12$ WEEKS

C HSI.F $=.5$

A DSLF, K $=A C O R P, K * N D D F$

C $N D U F=8$

A SLF, $K=B P, K$

WEEKS

NOTE

NOTE.

*** RETAIL ORIERING SURSYSTEH SEC.ONIIARY ***.

$L \quad$ RIS.K=RIS.JI (IIT) (SKS.JK+SFAS.JK-RSRS.JK)

N RIS=CORS WIVITCS

R RSFS, KL =COFS,K

A CORS.K=IIST (itSTE.F(SDS, TSUS))

C JDS $=125$

C SOS=0/TSDS $=24$

UNITS/WEEK

NOTE

NOTE. CONTROI. FOLICIES IN SECONDARY ORDFRING

$R$ RORS.KL $=$ TFIORS.K* $K(1-F A S, K)$

A TRDKS.K=ACORS.K+(CRTS.K+C.SL.S.K)

$L$ ACORS.K=ACORS.Jt (IIT/TACORS) (CORS.J-ACORS.J)

N ACDRS $=$ IDS

C TACOFS $=10$

A CRIS.K=(IIRIS,K-RIS.K)/TCRIS

C TCRIS $=10$

A DRIS, K=ACORS, K WNRICS

C NRICS $=10$

A CSI S.K $K=($ (DSL S.K-SIS,K)/TCSIS) *HSLEKS

C TCSLS $=12$ WEEKS

C USI.S $=.5$

A DSLS.K=ACORS, K*NDIS $*(1-F A S, K)$

C NDDS $=4$

A Sl.S. K $=$ BS $\cdot K$

HEEKS

WEEKS

NOTE

NOTE ALLOCATION OF SECONDARY RETAIL ORDERING

HEEKS

$L F A S, K=F A S . I+(D T)$ (CFAS.JK)

$N$ FAS $=0$

$R$ CFAS,KL.= (ISFAS, K-FAS,K)/TEAS

C TEAS $=50$

A DFAS. $K=$ TARHL. (TFAS, FRDNS. $K, 1, A, .5$ )

HEEKS

T TFAS $=0 / .1 / .4 / .7 / .9 / .95 / 1$

A PRDNS.K=SMOOTH (KITIS.K, TPRII)

C TPDD $=12$

HEEKS

00000001

00000002

$000000 \cap 3$

00000004

00000005

00000006

00000007

00000008

00000009

00000010

00000011

00000020

00000030

00000031

0000003 ?

00000033

000000.34

00000040

00000050

00000051

0000005 ?

00000060

00000061

00000070

00000071

00010080

00000081

00000082

00000090

00000091

00000100

00000101

00000102

00000103

00000110

00000111

00000120

00000130

000001.11

00000132

00000133

00000134

000001 A

00000150

00000160

00000161

0000016 ?

00000170

00000171

000001.80

00000181

00000190

00000191

00000192

00000200

00000201

$00000 ? 10$

000002.11

00000212

00000220

00000221

00000230

00000231

000002.40

00000241

000002.50

00000251

00000260

00000270

00000271

NOTE

NOTF

*** ALTERNATIUE SOURCE. **

$R$ ORAS, $K L=T R O R S, K * F A S, K$

$R$ SRAS.KL=NELAYI(ORAS.JK, NDES) 



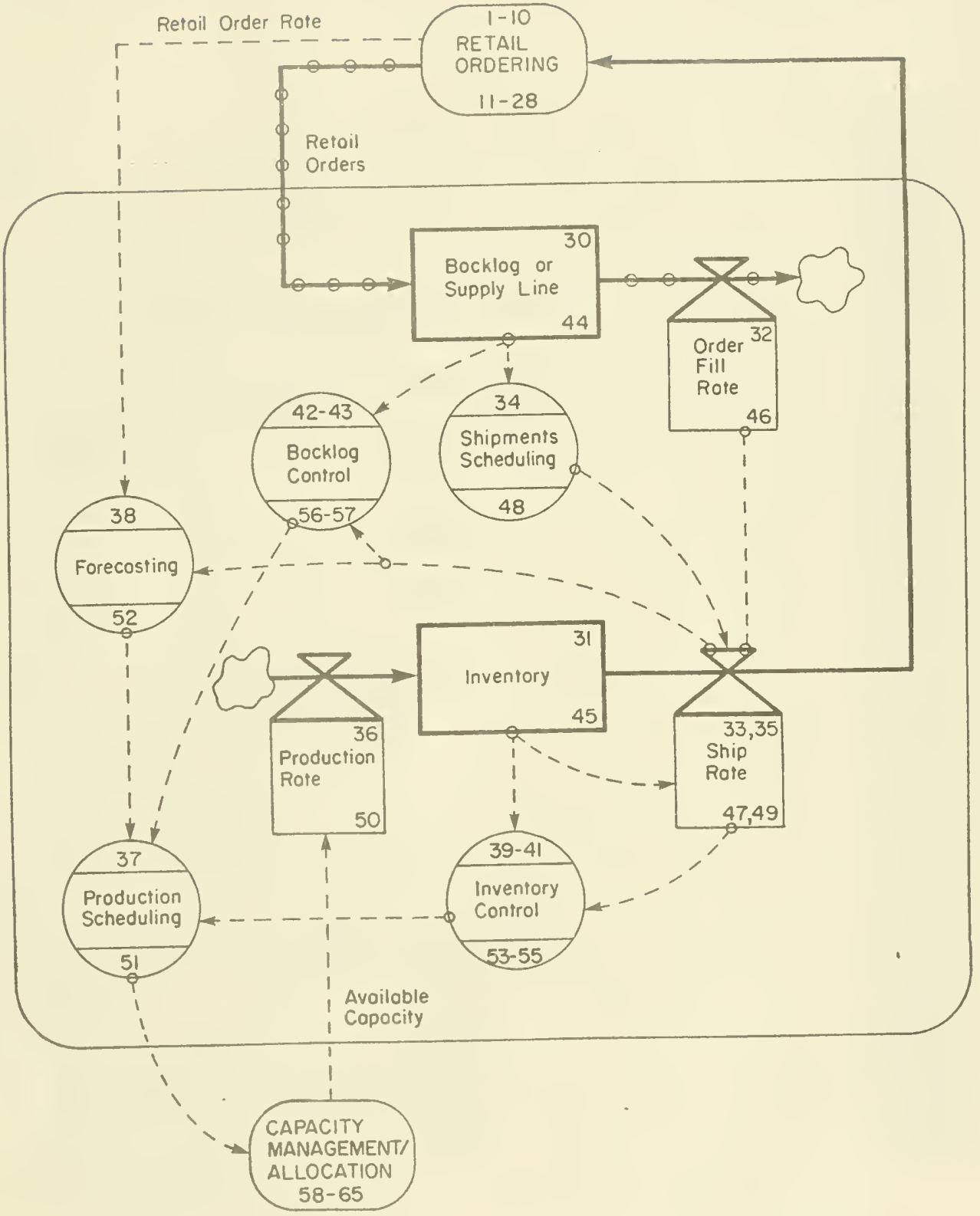

Figure A2. Policy Structure Diagram of Production Control Subunits 

NOTE ** PRONUCTION CONTROL. FRIMARY ***

NOTE

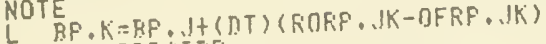

N $\mathrm{RP}=N I I I F \times T I I F$

$\mathrm{L} \quad I F, K=I F, I+!$
$N \quad I F=N I C F * I[I F$

R DFRF,KL=SFP.JK

R SRF, KL $=\Pi S E F, K * M I S F, K$

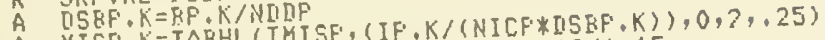

A MISF, K=TABHL (TMISF, (IF, K/N NICF $* 1 S B F, K)$

A TMISF $=0 /, 4 / .7 /, 9 /$
R F K F $K L=C, K * F A F: K$

NOTE CONTROL FOLICIES IN PKIMAFYY FROIIUCTION FI_ANNING NOTE C.ONTROL FOLICIES IN FKIMA

A FSP. K=AFORF, N $+(C, T F, K+C R F, K)$ (KOFF, JK-ARORF,J)

I ARORF, $K=A K$

N ARORF $=1$ TAR

A $C I P, K=(I I F, K-I F, K) / T C I F$

C TCIF $=16$

A DIF, K=ASFF, KNUICF

L ASRF, K=ASRF. J+(DT/TASFF) (SRF, ,K-ASFF. J)

$N$ ASFF $=I D F$

C TASRF $=10$

A $C B F, K=(B F, K-[I B F, K) / T C E F$

C TCBF $=16$

A $\Pi \mathrm{EF}, K=N D I F * A S R F, K$

NOTE ** FROIUCTION CONTFOI. SECONIAAYY ***

NOTE $, K=B S, J+(I I T)$ (FOKS. JK-OFRS, JK)

WFEKS

WFEKS

N B.S=NIDS*IIS

IS.K $=$ IS.Jt (IIT) (PRS.JK-SKS.JK)

$N$ IS=NICSKIIS

$R$ OFFS.KL=SKS. JK

$R$ SR. KL = NSBS.KNMISS.K

$A$ ISBS.K=HS.K/NIIIS

A MISS.K:TARHL.(TMISS, (TS,K/(NICS*ISSRS.K)), 0,2, 25)

T TMISS $=0 / .6 / .9 / .95 / 1 / 1.03 / 1.05 / 1.05 / 1.05$

$R \quad P R S, K L=C, K *(1-F A P, K)$

NOTE.

NOTE CONTROL. FOL.TCIES IN FRODUCTION PLANNING

A FSS, K=AFIOFIS. $K+$ (C.IS, K $+C B S, K$ )

ARORS =IIIS

c TARORS $=10$

A CIS.K $=($ IIS.K-IS.K) /TR.IS

C TCIS $=10$

A IIIS,K=ASRS.K*NICS

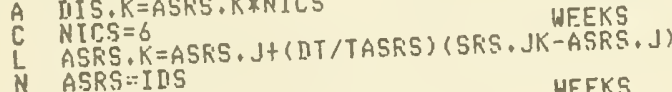

$N$ ASRS::IDS

C TASTS $=10$

A CBS.K $=($ BS. K K BRS,K)/TCBS

C TC.RS $=10$

A OBS,K=NIDS*ASRS, K
00000291

00010202

00000293

00000300

00000301

00000310

00000311

00000320

00000330

00000340

00000350

00000351

00000360

00000361

00000362

00000370

00000380

00000381

0000039,2

00000390

00000391

00000100

00000401

00000410

00000411

00000412

00000420

00000421

00000430

00000431

00000432

00000433

00000420

00000441

00000450

00000451

00000460

00000470

00000480

00000490

00000491

00000500

00000501

00000502

00000510

00000520

00000521

0000052 ?

00000530

00000531

00000540

00000541

0000055.0

00000551

00000552

00000560

00000561

000000570 



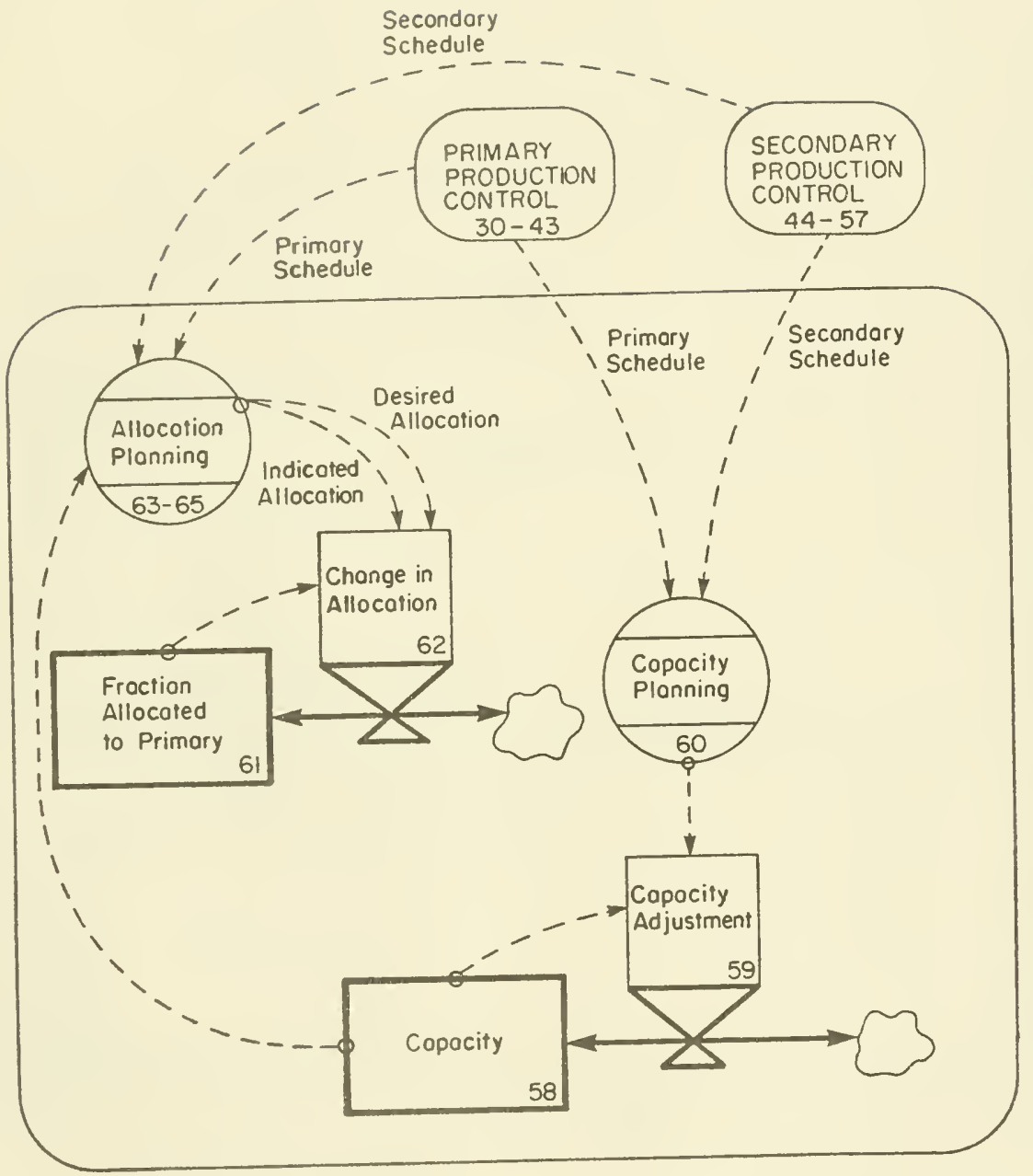



NOTE

NOTE *** CAPACITY MANAGEMEIT ANO AI.IOCATJON ***

NOTE

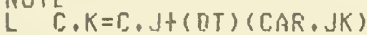

N $C=I D F+I D S$

$R \quad C A R, K I=\left(D, K, K-C_{,}, K\right) / T A C$

C $T A C=12$ WEEKS

A DC.K-SMOOTH( (FSP, K+FSS,K), TFC)

C $T F C=4$

NOTE

HEEKS

NOTE ALLOCATION FOLICY

$L \quad F A F, K=F A F, J+(\Pi T)$ ( $, F A F, J K)$

$N \quad F A F=I I F /(I I F+I I S)$

\& CFAP,KL $=(I I F A P, K * U D F, K+I F A F, K *(1-W D F, K)-F A P, K) / T A C P$

C $\mathrm{TACF}=4$

A DFAF,K $=F, S P, K / C, K$

A IFAF, K=FSF,K/(F'SF, KH+F'SS,K)

A UIIF, K $=$ TABHL. (TWDF, FAF, $K, . S, 1, .05$ )

$T$ TWEIF $=.2 / .2 /, 2 / .1 / 0$

NOTE

$S$ ARC . K $=I F A F, K / I F A F, K$

$S$ CDRT, K KCORF, KT CORS.K

NOTE

NOTE *** COYTROL STATEMENTS ***

SFEC IIT $=.5 /$ I.ENGTH $=0 / F$ LTFEF $=8 / F F T F$ TF $=0$

$P L O T$ DC, $=1, C=C, C O R T=T(1000,2200) / F A F=F(.6,1) / A R C=A$, UNF $: * *(0,2)$

PLQT CORS $=I, F S S=R, F \cdot R S=F(0,400) / M I S S=A(.5,2.5) / R I I I S=R(-1,3)$

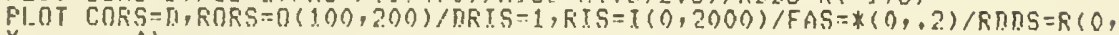
$x$ 4)

PI.OT CORF $=[1, R O R F=0(800,1.600) / D R I P=1, R I P=I$

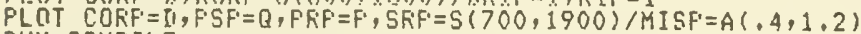

RUN COMPILE

CF' I.ENGTH $=32.0$

CP $S D P=+2$

CF SIS $=.2$

RUN GLOBAL

C $W S L F=1$

C NICP $=8$

C TCIF $=32$

C TCRF $=32$

c TASRF $=20$

C TARORF $=20$

PLOT CORS =II, ROFS $=0(100,200) / D F I S=1$, RIS $=I(0,2000) F A S=*(0,2) / F \cap I S=R(0,1)$ RUN GLOBAL,

00000571

00000572

00000573

00000580

00000581

00000590

00000591

00000600

00000601

00000602

00000603

00000610

00000611

00000,320

00000621

00000630

00000640

00000650

00000651

00000652

$000006 k 0$

00000,670

00000671

00000672

00000680

00000690

00000700

00000710

00000711

00000720

00000730

00000740

00000741

00000742

00000743

00000750

00000751

00000752

0000075

00000754

00000755

00000756

00000760

00000770 



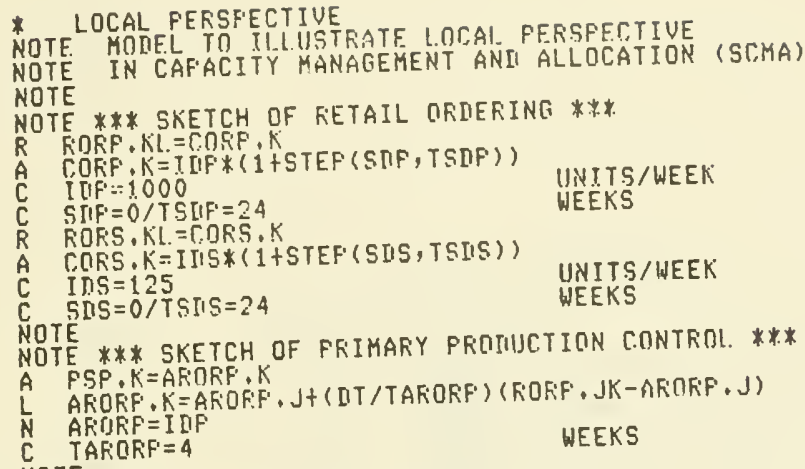

NOTE

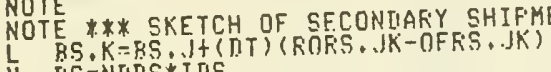

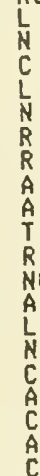

00000022 .

00000030

00000040

00000041

0000004 ?

00000043

00000044

00000050

00000060

00000061

00000063

00000063

00000064

00000070

00000071

00000072

00000080

00000081

00000090

00000100

00000110

00000120

00000121

00000130

00000131

00000140

00000150

00000151

$0000015 ?$

00000160

00000161

00000170

00000171

00000172

00000173

00000174

00000180

00000181

00000190

00000191

00000200

000002.01

00000702

000002.03

00000210

00000211

0000022 .

000002.21

00000230

00000240

00000250

$00 \times 002.51$

00000252

000002.60

00000270

000002.80

00000281

$00000 ? 82$

00000290

00000300

$00000 \pi 10$

00000320

$000003 \% 1$

00000322

00000323

00000324

00000330 



\section{LIST OF VARIABLES}

Smicol

ACORP

ACORS

ARC

ARORP

ARORS

ASRP

ASRS

$8 p$

is

c

$\begin{array}{lll}\text { CAR } & \text { A } & 59 \\ \text { CBP } & 4 & 42 \\ \text { CBS } & 4 & 56\end{array}$

CFAP

CFAS

CIP

cis

CORP

CORS

CORT

CRIP

CRIS

CSLP

csts

Dop

Des

DC

DOS

DFAP

DFAS

orp
T WHR-CMP

$\begin{array}{ll}L & 5 \\ 4 & 5.1 \\ L & 16 \\ 5 & 16.1 \\ 5 & 68\end{array}$

?

62

ค 23

A 38

4 53

4 3

A 13

s 67

a 6

a 17

a

a 19

* 43

- $\quad 57$

- 60

A 27

- 63

^ 24

- 40

DEFINITION

AVERAGE CUSTOMER OROER RATE PAIMARY (UNITS/WEEK) <5>

AVERAGE CUSTOMER OROER RATE SECONDARY (UNITS) WEEK) 〈16>

ALLOCATION RATIO FER CAPACITY (DIMENS IONLESS) <66>

AVERAGE RETAIL OROER RATE PRIMARY (UNITS/WEEK) <38>

AVERAGE RETAIL OROER RATE SECCNDARY (UNITS/WEEK) $\langle 52\rangle$

AVERAGE SHIP RATE PRIMARY (UNITS/WEEK) 〈AI〉

AVERAGE SHIP RATE SECONDARY (UNITS/WEEK) <55>

BACKLOG PRIMARY (UNITS) <3O>

BACKLOG SECONDARY (UNITS) 〈4A>

CAPACITY (UNITS/WEEK) <58>

CAPACITY ARRIYAL RATE (UNITS/WEEK/WEEK) <59) CORRECTION FOR BACKLOG PRIMARY (UNITS/WEEK) <42> CORRECTION FOR BACKLOG SECONOARY (UNITS/WEEK) <56>

CHANGE IN FRACTION ALLOCATEO TO PRIMARY (FRACTION/WEEK) <62〉

CHANGE IN FRACTION TO ALTERNATIVE SOURCE (FRACTION/WEEK) <23>

CORRECTION FOR INVENTORY PRIMARY (UNITS/WEEK) <39>

CORRECTION FOR INVENTORY SECONOARY (UNITS/WEEK) <53>

CUSTOMER OROER RATE PRIMARY (UNITS/WEEK) <3>

CUSTOMER OROER RATE SECONDARY (UNITS/WEEK) <13>

CUSTOMER ORDER RATE TOTAL (UNITS/WEEK) <67>

CORRECTION FOR RETAIL INVENTORY PRIMARY (UNITS/

WEEK) <6>

CORRECTION FOR RETAIL INVENTORY SECONOARY (UNITS/

WEEK) 〈17>

CORRECTION FOR SUPPLY LINE PRIMARY (UNITS/WEEK) $<8>$

CORRECTION FOR SUPPLY LINE SECONDARY (UNITS/

WEEK) <19>

DESIREO BACKLOG PRIMARY (UNITS) <43>

OESIREO BACKLOG SECONOARY (UNITS) <S?>

DESIREO CAPACITY (UNITS/WEEK) <6O>

DELIVERY DELAY SECONOARY (WEEKS) <27>

OESIRED FRACTION ALLOCATEO TO PRIMARY

(OIMENSIONLESS) <63>

OESIRED FRACTION TO ALTERNATIVE SOURCE

(OIMENSIONLESS) 〈24>

OESIREO INVENTORY PRIMARY (UNITS) <4O> 



\begin{tabular}{|c|c|c|c|}
\hline O\$3 & A & 54 & DESIRED INVENTORY SECONDARY (UNITS) <SA> \\
\hline ORIP & A & 7 & DESIRED RETAIL INVENTORY PRIMARY (UNITS) <7> \\
\hline DRIS & A & 18 & DESIREO RETAIL INVENTORY SECONDARY (UNITS) <1B> \\
\hline OSBP & $\mathbf{A}$ & 34 & $\begin{array}{l}\text { DESIRED SHIPMENTS FROM BACKLOG PRIMARY (UNITS/ } \\
\text { WEEK) <34> }\end{array}$ \\
\hline DSBS & A & 48 & $\begin{array}{l}\text { DESIRED SHIPMENTS FROM BACKLOG SECONDARY (UNITS/ } \\
\text { WEEK) } \angle A B>\end{array}$ \\
\hline OSLP & A & 9 & DESIRED SUPPLY LINE PRIMARY (UNITS) <9> \\
\hline osts & $\hat{\mathbf{C}}$ & $\begin{array}{l}20 \\
68\end{array}$ & DESRIED SUPPLY LINE SECONDARY (UNITS) <2O> \\
\hline FAP & L & $\begin{array}{l}61 \\
61.1\end{array}$ & $\begin{array}{l}\text { FRACTION ALLOCATED TO PRIMARY (DIMENSIONLESS) } \\
\langle 61\rangle\end{array}$ \\
\hline FAS & L & $\begin{array}{l}22 \\
22.1\end{array}$ & $\begin{array}{l}\text { FRACTION TO ALTERNATIVE SOURCE (DIMENSIONLESS) } \\
\text { <22> }\end{array}$ \\
\hline TOP & c & 3.1 & INITIAL DEMAND PRIMARY (UNITS/WEEK) <3> \\
\hline $\begin{array}{l}\text { IOS } \\
\text { IFAP }\end{array}$ & C & $\begin{array}{l}13.1 \\
64\end{array}$ & $\begin{array}{l}\text { INITIAL DEMAND SECONOARY (UNITS/WEEK) <13> } \\
\text { INDICATED FRACTION ALLOCATEO TO PRIMARY } \\
\text { (DIMENSIONLESS) <6A> }\end{array}$ \\
\hline IP & $\stackrel{1}{N}$ & $\begin{array}{l}31 \\
31.1\end{array}$ & INVENTORY PRIMARY (UNITS) 〈3I> \\
\hline IS & $\mathbf{L}$ & 45 & INVENTORY SECONDARY (UNITS) 《4S〉 \\
\hline LENGTH & C & 68 & \\
\hline UISP & A & 35 & $\begin{array}{l}\text { MULTIPLIER FROM INVENTORY ON SHIPMENTS PRIMARY } \\
\text { (OIMENSIONLESS) <3S> }\end{array}$ \\
\hline uIsS & A & 49 & $\begin{array}{l}\text { WULTIPLIER FROM INVENTORY ON SHIPMENTS SECONDARY } \\
\text { (OIMENSIONLESS) <49> }\end{array}$ \\
\hline NODP & c & 9.1 & \\
\hline $\begin{array}{l}\text { NDDS } \\
\text { MICP }\end{array}$ & C & 20.1 & NORMAL DELIVERY DELAY SECONDARY (WEEKS! Q2O) \\
\hline NICS & c & $\begin{array}{l}40.1 \\
54.1\end{array}$ & $\begin{array}{l}\text { NORMAL INVENTORY COVERAGE PRIMARY (WEEKS) <4O> } \\
\text { NORMAL INVENTORY COVERAGE SECONOARY (WEEKS) <54> }\end{array}$ \\
\hline NRICP & C & 7.1 & $\begin{array}{l}\text { NORMAL RETAIL INVENTORY COVERAGE PRIMARY (WEEKS) } \\
\text { <T> }\end{array}$ \\
\hline NRICS & C & 18.1 & $\begin{array}{l}\text { NORMAL RETAIL INVENTORY COVERTAGE SECONDARY } \\
\text { (WEEKS) SIB> }\end{array}$ \\
\hline $\begin{array}{l}\text { OFRP } \\
\text { OFRS }\end{array}$ & $\begin{array}{l}\mathbf{R} \\
\mathbf{R}\end{array}$ & $\begin{array}{l}32 \\
46\end{array}$ & $\begin{array}{l}\text { ORDER FILL RATE PRIMARY (UNITS/WEEK) <32> } \\
\text { ORDER FILL RATE SECONDARY (UNITS/WEEK) <46> }\end{array}$ \\
\hline ORAS & $\ddot{R}$ & 28 & $\begin{array}{l}\text { ORDER RATE TO ALTERNATIVE SOURCE (UNITS/WEEK) } \\
\text { S2B> }\end{array}$ \\
\hline PLTPER & C & 68 & \\
\hline PRDDS & A & 25 & $\begin{array}{l}\text { PERCEIVED RELATIVE DELIVERY DELAY SECONDARY } \\
\text { (DIMENSIONLESS) <2S> }\end{array}$ \\
\hline $\begin{array}{l}\text { PRP } \\
\text { PRS }\end{array}$ & $\mathbf{R}$ & 36 & PRODUCTIDN RATE PRIMARY (UNITS/WEEK) 〈36> \\
\hline $\begin{array}{l}\text { PRS } \\
\text { PRTPER }\end{array}$ & $\mathbf{R}$ & $\begin{array}{l}50 \\
68\end{array}$ & PRODUCTION RATE SECONOARY (UNITS/WEEK) 〈SO〉 \\
\hline PSP & A & 37 & PRODUCTION SCHEDULE PRIMARY (UNITS/WEEK) $\langle 37\rangle$ \\
\hline PSS & A & 51 & PRODUCTION SCHEDULE SECONDARY (UNITS/WEEK) 〈SI〉 \\
\hline Roos & A & 26 & $\begin{array}{l}\text { RELATIVE DELIVERY DELAY SECONDARY } \\
\text { (OIMENSIONLESS) }: 2 E S\end{array}$ \\
\hline AIP & W & 1.1 & RETAIL INVENTORY PRIMARY (UNITS) <I> \\
\hline aIS & $\mathbf{L}$ & $\begin{array}{l}11 \\
11.1\end{array}$ & RETAIL INVENTORY SECCONDARY (UNITS) 〈II〉 \\
\hline RORP & $\mathbf{R}$ & 4 & RETAIL DDER RATE PRIMARY (UNITS/WEEK) 〈A> \\
\hline ASRP & $\begin{array}{l}\mathbf{R} \\
\mathbf{R}\end{array}$ & 2 & $\begin{array}{l}\text { RETAIL OROER RATE SECONDARY (UNITS/WEEK) <14> } \\
\text { RETAIL SHIP RATE PRIMARY (UNITS/WEEK) <2> }\end{array}$ \\
\hline
\end{tabular}





\begin{tabular}{|c|c|c|c|}
\hline es:s & ? & 12 & 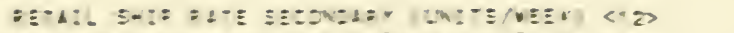 \\
\hline $5:=$ & 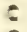 & 3.2 & 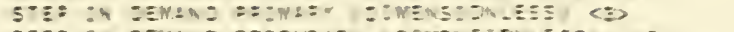 \\
\hline s:5 & $\Xi$ & 13.2 & 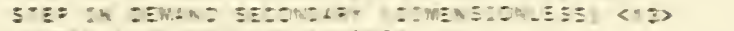 \\
\hline $5:-2$ & $\Lambda$ & $s=$ & 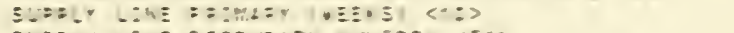 \\
\hline $5: 5$ & 1 & 21 & 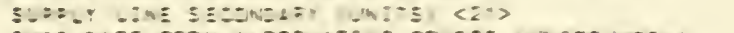 \\
\hline $5=1.5$ & $\bar{z}$ & 25 & 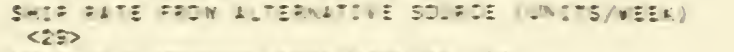 \\
\hline 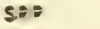 & $\approx$ & 33 & 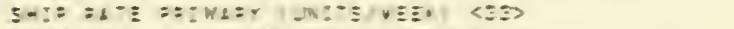 \\
\hline $5=5$ & $\overline{-}$ & $5=$ & 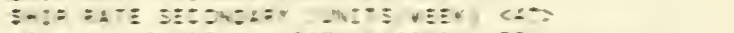 \\
\hline T1: & 气 & Sร.: & 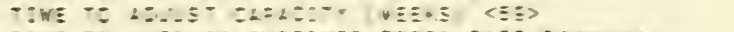 \\
\hline$\because 120: 5$ & $=$ & 5.2 & 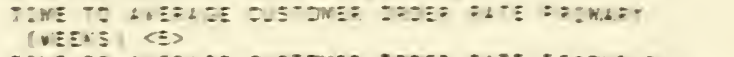 \\
\hline $71=5=5$ & $=$ & $i \lesssim .2$ & 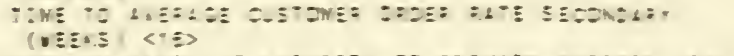 \\
\hline $11: 2$ & 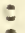 & $5:-1$ & 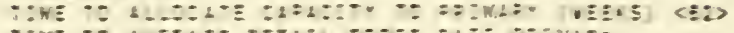 \\
\hline i\ะ2:2 & $=$ & $\Xi \Xi .2$ & 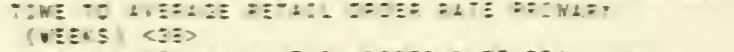 \\
\hline i $1:=: 5$ & $=$ & 52.2 & 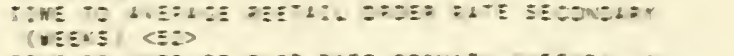 \\
\hline $145 \div$ & 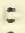 & 41.2 & 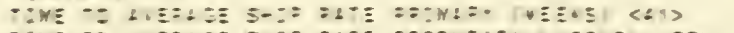 \\
\hline$: 15: 5$ & $\varepsilon$ & $5 \Xi \ldots$ & 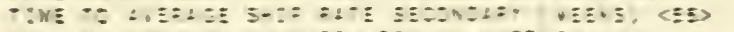 \\
\hline$i \div \bar{\Sigma}=$ & $=$ & 42.9 & 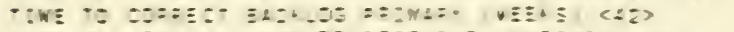 \\
\hline$i \div \pm 5$ & 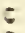 & $5 \Xi-1$ & 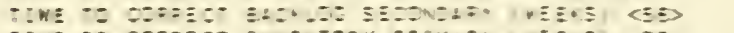 \\
\hline$:=: 2$ & $=$ & $\Sigma \equiv .1$ & 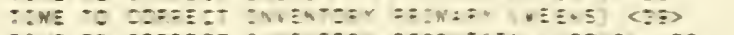 \\
\hline $1:: 5$ & E & $\Xi 3.9$ & 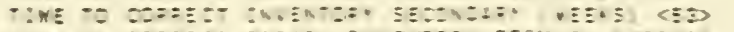 \\
\hline Tะネ: : & $=$ & $\vdots .1$ & 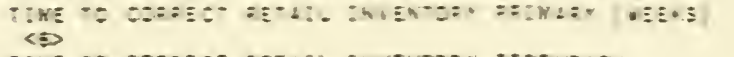 \\
\hline TC: :5 & 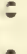 & १:. 9 & 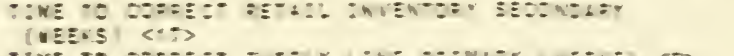 \\
\hline$i=5: 7$ & 5 & ま. & 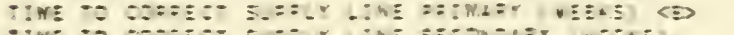 \\
\hline$\tau=5: 5$ & $=$ & ร.ร & 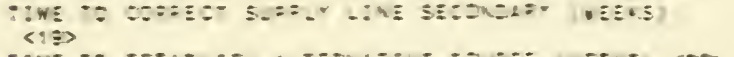 \\
\hline YES & 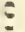 & 23.1 & 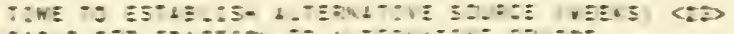 \\
\hline$\because \$ 15$ & 氵 & 24.8 & 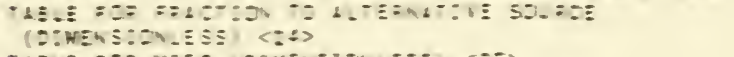 \\
\hline ix:s= & $\because$ & 35.9 & 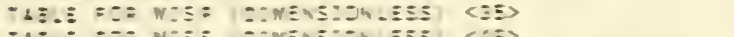 \\
\hline $7: 53$ & 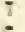 & $4 \equiv .:$ & 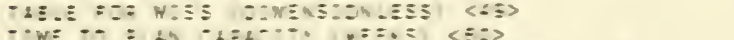 \\
\hline 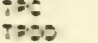 & $\vdots$ & $5=\vdots$ & 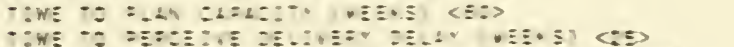 \\
\hline$t a z=2$ & $\dot{i}$ & $: 5$ & 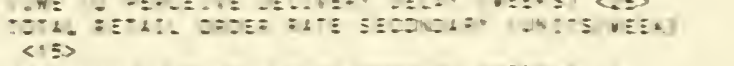 \\
\hline is:? & 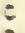 & $\vdots-2$ & 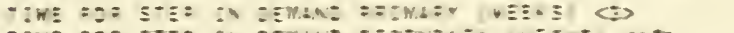 \\
\hline $75=5$ & 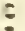 & 13. & 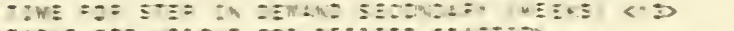 \\
\hline Tots & $i$ & 55.1 & 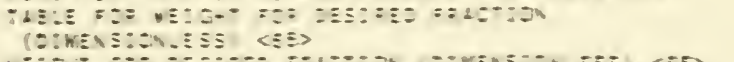 \\
\hline 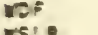 & 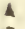 & 65 & 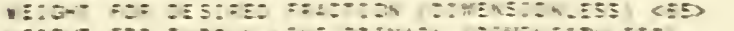 \\
\hline ISLO & $=$ & 5.2 & 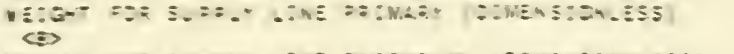 \\
\hline is Ls & $\epsilon$ & 19.2 & 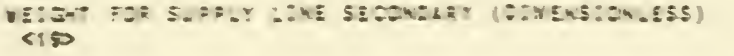 \\
\hline
\end{tabular}





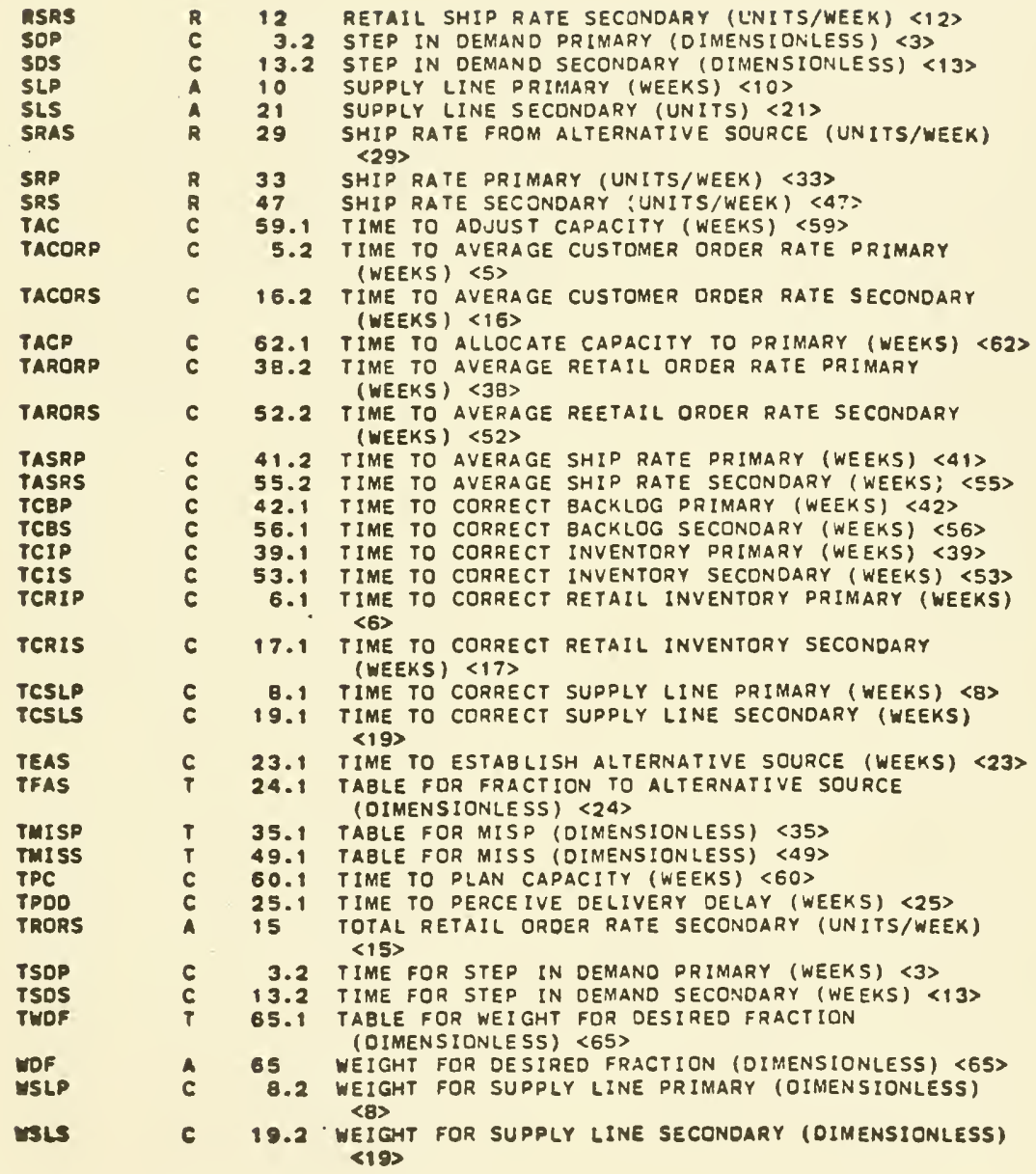



$11-12-8$ 

H028.M414 no. 1331- 82A

Morecroft, Joh/Managing product lines

744967 D*BKS 00134562

39080002019450 
